\title{
Surgical Management of Ptosis - Visual Function and Cosmetic Outcome
}

\author{
Hendriati \\ hendriati@med.unand.ac.id \\ Department of Opthalmology, Faculty of Medicine Andalas University, Dr. M. Djamil Hospital Padang
}

\begin{abstract}
Ptosis may cover a significant portion pupillary aperture so as to cause visual impairment. The treatment of ptosis requires accuracy of surgical techniques to implement a functional and cosmetic correction.We aim to determine the visual function and cosmetic result following the surgical correction of congenital and acquired ptosis at oculoplastic surgery subdivision department of ophthalmology M Djamil Hospital in Padang. A retrospective review of 30 eyes of 21 cases that had congenital and acquired ptosis between april 2012 and march 2015. 12 cases (14 eyes) underwent ptosis repair where 5 eyes were operated by levator resection, 7 eyes operated by frontalis suspension using fascia latta, 2 eyes operated by Y-V plasty. We analized the percentage of cause and degree of ptosis, visual function and cosmetic outcome after surgery. We found $11(51 \%)$ cases had congenital ptosis and 10(49\%) had acquired ptosis. $9(43 \%)$ cases were bilateral and 12 $(57 \%)$ cases were unilateral. Most of our patient had severe ptosis $(53 \%)$ with levator function was fair in $14(47 \%)$ eyes. Of 14 eyes underwent surgery, good visual function outcome (MRD1 $\geq 2 \mathrm{~mm}$ ) were achieved in $86 \%$ (6/7) eyes whom operated by frontalis suspension using fascia latta, $80 \%$ (4/5) eyes whom operated by levator resection procedure and $100 \%(2 / 2)$ whom operated by Y-V plasty. Good cosmetic outcome achieved in 7(58\%) cases after 1 month follow up.
\end{abstract}

Keywords : Congenital, acquired, ptosis, surgery, cosmetics.

\section{Introduction}

Ptosis is defined as abnormal drooping of superior eyelid during primary position of the eye. Congenital ptosis occurs during labor or the first year of life. The most common congenital ptosis is local myogenic dystrophy of levator palpebrae superior (LPS). Several congenital ptosis are resulted from genetic or chromosome defect or neurological disfunction. Congenital ptosis is also related with blepharophimosis syndrome (5\%) and sinkinesis ptosis such as Marcus Gunn Jaw winking ptosis and N.III ptosis [1].

Ptosis is classified into neurogenic, myogenic, aponeurotic, and mechanical ptosis. Aponeurotic ptosis appears as the most common cause of ptosis including involutional change, weakness, or incorrect insertion of LPS [2].

The abnormal drooping of superior eyelid may cover pupil aperture and lead to visual disturbance, decrease peripheral visual field, and patient may show chin up backward head tilt position as compensation and difficulty reading [2,3].

Ptosis surgery is aimed to elevation of superior eyelid and provides functional and cosmetic benefit. From functional perspective, the goal of surgery is to achieve elevation of superior eyelid margin above pupil axis to improve superior visual field. From cosmetic prospective, the goal of surgery is to achieve normal eyelid margin curvature, symmetrical eyelid margin height, and symmetrical eyebrow [3]. 
This study aims to investigate visual function and cosmetic outcome of ptosis patient who underwent levator resection, frontalis suspension procedure with fascia lata and $\mathrm{Y}-\mathrm{V}$ plasty in subdivision of reconstruction and occuloplastic of Dr. M. Djamil General Hospital.

\section{Methods}

This was a retrospective descriptive study involving ptosis patients who underwent levator resection, frontalis suspension procedure with fascia lata and $\mathrm{Y}-\mathrm{V}$ plasty in Dr. M. Djamil Central Hospital from April 2012 to March 2015. Data was obtained secondarily from medical record and categorised based on ptosis diagnosis, stage, surgical procedure, cosmetic outcome, and patient visual function. Cosmetic outcome was evaluated from both eyelid symmetry after one month follow up. Cosmetic outcome was categorised as good if both eyelids dyssymmetry was less than $1 \mathrm{~mm}$, mild if both eyelid asymmetry was $1,5 \mathrm{~mm} 22 \mathrm{~mm}$, and poor if both eyelid asymmetry was more than $2 \mathrm{~mm}$. Visual function outcome was evaluated by opening of visual axis from eyelid elevation after ptosis procedure with 1 month follow up. Improvement was defined as $\mathrm{MRD}_{1}+2$, and $\mathrm{MRD}_{1}$ less than +2 was defined as no improvement.

\section{Result}

During the period of April 2012 to March 2015, as many as 21 ptosis with involvement of 30 eyelid, 9 cases $(42,9 \%)$ were unilateral and $12(57,1 \%)$ were bilateral. The majority of patients were $11-20$ years old $(38,1 \%)$, with the youngest 4,5 years old and the oldest 70 years old. Twelve cases $(57,1 \%)$ affected male and 9 cases $(42,9 \%)$ affected female. Table 1 shows the distribution of ptosis based on sex.

Table 1. Distribution based on age group and sex

\begin{tabular}{|c|c|c|c|}
\hline \multirow{2}{*}{ Age group (year) } & \multicolumn{2}{|l|}{ Sex } & \multirow{2}{*}{ Total } \\
\hline & Male & Female & \\
\hline $0-10$ & 4 & - & $4(19,1 \%)$ \\
\hline $11-20$ & 4 & 4 & $8(38,1 \%)$ \\
\hline $21-30$ & 2 & 3 & $5(23,8 \%)$ \\
\hline $31-40$ & - & - & $-(0 \%)$ \\
\hline $41-50$ & - & 2 & $2(9,5 \%)$ \\
\hline $51-60$ & 1 & - & $1(4,75 \%)$ \\
\hline $61-70$ & 1 & - & $1(4,75 \%)$ \\
\hline Total & $12(57 \%)$ & $9(43 \%)$ & $21(100 \%)$ \\
\hline
\end{tabular}

Based on table 1, most of the patient were in the age range of 11-20 years old, while the least is age of 31-40 years old ( $0 \%)$. Table 2 shows ptosis distribution based on eyelid laterality. 
Table 2. Ptosis distribution based on eyelid laterality

\begin{tabular}{lll}
\hline Laterality & Total (case) & $\%$ \\
\hline Unilateral & 9 & 42.9 \\
Bilateral & 12 & 57.1 \\
\hline Total & 21 & 100 \\
\hline
\end{tabular}

Based on table 2, most of the cases were bilateral ptosis $(57,1 \%)$, while the remains $(43,9 \%)$ were unilateral cases. Table 3 shows ptosis distribution based on classification.

Table 3. Ptosis distribution based on classification

\begin{tabular}{llll}
\hline Ptosis category & $\begin{array}{l}\text { Total } \\
\text { (individual) }\end{array}$ & $\%$ \\
\hline Congenital & Isolated congenital & 10 & 47.6 \\
& $\begin{array}{l}\text { Blefarofimosis } \\
\text { Syndrome }\end{array}$ & 1 & 4.7 \\
Acquired & Myasthenia gravis & 2 & \\
& CPEO & 2 & 9.5 \\
& Neurogenic & 1 & 9.5 \\
& Traumatic & 1 & 4.7 \\
& Aponeurosis & 4 & 4.7 \\
\hline & Total & 21 & 19.3 \\
\hline
\end{tabular}

Tabel 3 shows the classification of ptosis with most of the cases is isolated congenital $(47,6 \%)$ and acquired ptosis were 11 cases $(52,3 \%)$ and 10 cases $(47,7 \%)$, respectively. Congenital ptosis was accounted for almost half of the case. Table 4 shows ptosis stage based on levator function.

Table 4. Ptosis stage based on levator function

\begin{tabular}{lllll}
\hline \multicolumn{1}{c}{$\begin{array}{c}\text { Ptosis } \\
\text { category }\end{array}$} & \multicolumn{3}{c}{ Levator function (eyelid) } & Total \\
\cline { 2 - 5 } & $\begin{array}{l}\text { Good } \\
(\geq 8 \mathrm{~mm})\end{array}$ & $\begin{array}{l}\text { Moderate } \\
(5-7 \mathrm{~mm})\end{array}$ & $\begin{array}{l}\text { Poor } \\
(\leq 4 \mathrm{~mm})\end{array}$ & \\
\hline $\begin{array}{l}\text { Isolated congenital } \\
\begin{array}{l}\text { Sindrom } \\
\text { blefarofimosis }\end{array}\end{array}$ & 1 & 2 & 10 & $13(43.3 \%)$ \\
Myasthenia gravis & - & 2 & - & $2(6.7 \%)$ \\
\end{tabular}




\begin{tabular}{lllll} 
CPEO & - & 4 & - & $4(13.3 \%)$ \\
Neurogenic & 1 & - & - & $1(3.3 \%)$ \\
Traumatic & & 1 & - & $1(3.3 \%)$ \\
Aponeurosis & 3 & 2 & - & $5(16.7 \%)$ \\
\hline Total & 5 & $15(50 \%)$ & $10(33,3 \%)$ & $30(100 \%)$ \\
& $(16.7 \%)$ & & & \\
\hline
\end{tabular}

Based on table 4, almost $50 \%$ of ptosis had moderate levator function, and majority congenital ptosis patients had poor levator function $(33,3 \%)$. Table 5 shows Stage of ptosis based on eyelid drooping compared with normal eyelid.

Table 5. Stage of ptosis based on eyelid drooping compared with normal eyelid

\begin{tabular}{lllll}
\hline Ptosis category & \multicolumn{3}{l}{ Eyelid drooping compared with normal } & \multirow{2}{*}{ Total } \\
\cline { 2 - 4 } & $\begin{array}{l}\text { Mild } \\
(\leq 2 \mathrm{~mm})\end{array}$ & $\begin{array}{l}\text { Moderate } \\
(3 \mathrm{~mm})\end{array}$ & $\begin{array}{l}\text { Severe } \\
(\geq 4 \mathrm{~mm})\end{array}$ & $13(43.3 \%)$ \\
\hline $\begin{array}{l}\text { Isolated } \\
\text { congenital }\end{array}$ & 2 & 3 & & $2(6.7 \%)$ \\
$\begin{array}{l}\text { Sindrom } \\
\text { blefarofimosis }\end{array}$ & - & - & 2 & $4(13.3 \%)$ \\
$\begin{array}{l}\text { Myasthenia } \\
\text { gravis }\end{array}$ & - & 4 & - & $4(13.3 \%)$ \\
CPEO & 1 & 1 & 2 & $1(3.3 \%)$ \\
Neurogenik & - & - & 1 & $1(3.3 \%)$ \\
Traumatic & - & - & 1 & $5(16.7 \%)$ \\
Aponeurosis & 1 & 1 & 3 & $30(100 \%)$ \\
\hline Total & $4(13.3 \%)$ & $9(30 \%)$ & $17(56.7 \%)$ &
\end{tabular}

Based on table 5, the majority of ptosis case in this study was severe ptosis $(56,7 \%)$ and almost half of them were congenital. Table 6 shows type of ptosis surgery carried on in each patient.

Table 6. Ptosis surgery

\begin{tabular}{|c|c|c|c|c|}
\hline \multirow[t]{2}{*}{ Ptosis category } & \multicolumn{3}{|c|}{ Ptosis surgery (eyelid) } & \multirow[t]{2}{*}{ Total } \\
\hline & $\begin{array}{l}\text { Levator } \\
\text { resection }\end{array}$ & $\begin{array}{l}\text { Frontal } \\
\text { is }\end{array}$ & $\begin{array}{l}Y-\quad V \\
\text { plasty }\end{array}$ & \\
\hline
\end{tabular}




\begin{tabular}{lllll}
\hline & \multicolumn{3}{c}{$\begin{array}{l}\text { suspens } \\
\text { ion }\end{array}$} \\
\hline Kongenital & 1 & 7 & - & 8 \\
& & & $(57.2 \%)$ \\
Sindrom & - & - & 2 & 2 \\
blefarofimosis & & - & - & $(14.2 \%)$ \\
Aponeurosis & 2 & - & - & $(14.2 \%)$ \\
Traumatik & 1 & - & - & $1(7.1 \%)$ \\
CPEO & 1 & $7(50 \%)$ & 2 & 14 \\
\hline Total & $5(35.7 \%)$ & $(14.2 \%)$ & $(100 \%)$ \\
\hline
\end{tabular}

Based on table 6 , there were 14 ptosis cases that underwent surgery, majority of them underwent frontalis suspension procedure with fascia lata $(50 \%)$, followed by levator resection, and Y-V plasty. Almost all of the congenital ptosis (7/8) were treated with frontalis suspension procedure with fascia lata, and blepharophymosis syndrome $(2 / 2)$ were treated with Y-V plasty. Table 7 shows visual function outcome.

Tabel 7. Visual function outcome

\begin{tabular}{lccc}
\hline Surgery technique & \multicolumn{2}{c}{ Visual function outcome } & Total \\
\cline { 2 - 4 } & $\begin{array}{l}\mathrm{MRD}_{1}+2 \\
\text { (eyelid) }\end{array}$ & $\begin{array}{l}\text { MRD }_{1}<+2 \\
\text { (eyelid) }\end{array}$ & \\
\hline $\begin{array}{l}\text { Frontalis suspension } \\
\text { with fascia lata }\end{array}$ & 6 & 1 & $7(50 \%)$ \\
$\begin{array}{l}\text { Levator resection } \\
\text { Y to } V\end{array}$ & 4 & 1 & $5(35,7 \%)$ \\
\hline Total & 2 & - & $2(14,3 \%)$ \\
\hline
\end{tabular}

Based on table 7 , most of the patients $(85,7 \%)$ achieved good visual outcome function after underwent ptosis surgery with frontalis suspension (6/7), levator resection(4/5), and $\mathrm{Y}-\mathrm{V}$ plasty $(2 / 2)$ procedure after one month follow up. Table 8 shows the cosmetic outcome of ptosis surgery.

Tabel 8. Cosmetic Outcome

\begin{tabular}{llll}
\hline $\begin{array}{l}\text { Surgery } \\
\text { technique }\end{array}$ & \multicolumn{2}{c}{ Assymetry between 2 eyelid } & \multirow{2}{*}{ Total } \\
\cline { 2 - 3 } & $\begin{array}{lll}\text { Good } \\
(\leq 1 \mathrm{~mm})\end{array}$ & $\begin{array}{l}\text { Mild } \\
(1.5-2 \mathrm{~mm})\end{array}$ & $\begin{array}{l}\text { poor } \\
\end{array}$ \\
& & &
\end{tabular}




\begin{tabular}{lllll}
\hline $\begin{array}{l}\text { Levator } \\
\text { resection }\end{array}$ & 5 & - & - & $5(41.7 \%)$ \\
$\begin{array}{l}\text { Frontalis } \\
\text { suspension }\end{array}$ & 2 & 3 & 1 & $6(50 \%)$ \\
Y-V plasty & 1 & - & - & $1(8.3 \%)$ \\
\hline Total & 8 & $3(25 \%)$ & $1(8.3 \%)$ & $12(100 \%$ \\
& $(66.7 \%)$ & & & ) \\
\hline
\end{tabular}

Table 8 shows that from 5 cases treated with levator resection, all of them achieved good cosmetic outcome. Meanwhile, 6 cases that were treated with frontalis suspension with fascia lata, the result was 2, 3, and 1 cases showed good, moderate, and poor cosmetic outcome respectively. One casetreated with Y-V plasty was blepharophymosis syndrome and showed good cosmetic outcome.

\section{Discussion}

During April 2012 to March 2015 period, there were 21 ptosis cases with 30 eyelids involvement that visited outpatient eye clinic of Dr. M. Djamil Central Hospital, Padang. Out of 21 cases, 9 cases affected 1 eyelid and 12 cases affected both eyelids. The most common age was 11-20 years old $(38,1 \%)$ where the youngest was 4,5 years and the oldest was 70 years old. More than half cases $(57 \%)$ were dominated by male, and the rest were female $(43 \%)$ with the most common cause was simple congenital ptosis $(47,6 \%)$. Study by Griepentord et al investigating incidence and ptosis demography, where majority of ptosis were dominated by male $(55 \%)$ and the rest were female (45\%), with mean age was under 19 years old, and 84,3\% were diagnosed with simple congenital ptosis [1].

Baiyeroju et al observed 25 ptosis cases for 5 years and showed $52 \%$ were younger than 16 years old and only $8 \%$ were over 50 years old. Male to female ratio was $1: 1$, majority affecting one eye and $56 \%$ cases were congenital [2].

Our study showed majority of congenital ptosis had poor levator function and severe ptosis. This was in accordance with theory where majority of congenital ptosis were caused by myogenic dysgenesis of levator muscle, where fibrous and adipose tissue cause decrease in function of muscle contraction and affect levator contraction and lift eyelid [2], [3], [4].

From 21 cases in our study, only 12 cases that underwent ptosis surgery with 2 cases were bilateral ptosis. Two ptosis cases in myasthenia gravis and in CPEO case were consulted to neurology departement to continue medical treatment. There were three congenital ptosis underwent observation because no visual axis disturbance was found. Aponeurosis ptosis was found in two cases, 1 cases was not eligible for surgery because negative bell's phenomenon and 1 patient refused to undergo surgery. In patient with negative bell's phenomenon, ptosis surgery increases infection risk because lagoftalmus [5].

Procedure of choice in ptosis depends on ptosis type, stage, and levator muscle function. Levator function is an important assessment in surgical planning. In severe ptosis and poor levator function, frontalis suspension is therapy of choice. In this study, 5 patients with moderate levator function, underwent levator resection surgery, meanwhile 7 patients with severe ptosis 
and poor levator function $(\leq 4 \mathrm{~mm})$, underwent frontalis suspension procedure with fascia lata from the patient's body. The reason of using fascia lata is because lower risk of infection, extrusion, rupture, and good viability and compatibility [6], [7].

There were 6 of 7 congenital ptosis patients who underwent frontalis suspension with fascia lata and showed excellent visual function outcome. These 6 patients achieved $\mathrm{MRD}_{1}+2$ after 1 month follow up. In accordance with study by Rizvi et al, frontalis suspension procedure showed susccess rate of $82,6 \%$ [6].

Skaat et al conducted frontalis suspension procedure with several sling material including PTFE, silicone rod, fascia lata, and mersilene mesh. Visual function was achieved in almost all patients, however the recurrence rate in mersilene mesh $(36.4 \%)$, fascia lata $(20 \%)$ dan silicone $\operatorname{rod}(100 \%)$ was quite high. ${ }^{17} \mathrm{Kim}$ et al showed improvement of vertical eyelid fissure was about $3.24 \pm 1.14 \mathrm{~mm}$ after frontalis suspension surgery with fascia lata in congenital ptosis [8].

Our study showed 1 case that showed FPV improvement of $1 \mathrm{~mm}$ but not good enough for visual function improvement. Probability of aponeurosis levator weakness and LPS dysfunction were suspected in this patient.

Levator resection may result in good outcome in ptosis with good levator function. Cates and Tyers reported the success rate was about $75 \%$ out of 100 congenital ptosis patients who underwent levator resection procedure. As many as 5 ptosis patients with levator function greater than $4 \mathrm{~mm}$ were treated with levator resection [6].

As many as 4 out of 5 ptosis patient showed good visual function with $\mathrm{MRD}_{1}+2$, and only 1 patient with failure with the CPEO as the underlying condition, and previously had levator resection surgery (recurrent case). Rizvi et al showed success rate of levator resection as much as $76 \%$ in ptosis with levator function greater than $4 \mathrm{~mm}$. Berlin et al showed success rate $69 \%$ in 52 cases congenital ptosis. Jordan et al showed success rate of $43 \%$ in 288 levator resection cases. Majority of studies showed levator function with ptosis stage before surgery was strongly correlated with levator resection outcome [6].

Experts may had different opinion regarding surgery of choice in ptosis in CPEO. Schaefer suggested frontalis suspension with fascia lata in every young patient, with under correction of 1-2 mm.11 Meanwhile other author decided the surgery of choice based on levator function [9], [10].

Lane and Colin conducted a study in 17 CPEO patient, levator advancement was conducted in 7 patients with levator function greater than $4 \mathrm{~mm}$ and showed increased eyelid aperture about $7,6 \mathrm{~mm}$. In 8 patients who underwent frontalis suspension with fascia lata, there was increased of eyelid aperture about $6,5 \mathrm{~mm}$. Furthermore, 2 other patients who underwent ptosis prop also showed excellent outcome [10].

Wong et a prefer frontalis suspension as surgery of choice in ptosis with levator function less than $8 \mathrm{~mm}$. They believe that by using sling material was more effective because CPEO is naturally progressive and levator resection procedure does not correct ptosis in long term. Big Levator resection is also unfavourable because it increased risk of infection due to lagoftalmus in patient with negative bell's phenomenon [5].

This study found 1 blepharophymosis syndrome. Blepharophymosis procedure may be done in 1 step where Y-V plasty was done simultaneously with frontalis suspension, 2 two steps where $\mathrm{Y}-\mathrm{V}$ plasty and frontalis suspension are conducted in different time. In this study, Y-V plasty was done to repair telechantus and epicanthus in versus, and resulted in excellent cosmetic and visual function [11], [12].

All 12 cases were resulted in good, moderate, and poor cosmetic function as many as 8 (66.7\%), 3 (25\%), and 1 (8.3\%) cases, respectively. This study showed the acceptable cosmetic 
outcome was $91,7 \%$ case, meanwhile poor cosmetic outcome required second surgery. One of the cosmetic benefit of ptosis surgery is symmetry of both eyelid, symmetry of FPV from bot eyelids, and symmetry of eyelids and eyebrow [13].

Rizvi et al reported good cosmetic outcome was achieved in $79 \%$ cases, moderate in $12 \%$ cases, and poor in $9 \%$ cases from 57 congenital and acquired ptosis with various surgery technique based on levator function. This study found only 1 case that needed second surgery.

\section{Conclusion}

Ptosis surgery procedure is determined based on levator function where levator resection is done in ptosis with levator function greater than $4 \mathrm{~mm}$, and frontalis suspension in ptosis with levator function lower than $4 \mathrm{~mm}$. This procedure resulted in excellent visual and cosmetic function. Ptosis in CPEO needs second surgery because CPEO is a progressive condition and surgery will be done if ptosis covers visual axis. Different Surgery technique in CPEO needs to be considered to improve succes rate.

\section{Refferences}

Griepentorg GJ, Diehl N, Mohney BG. Incidence and Demographics of Chilhood Ptosis. Ophthalmology 2011: 118(6).pp. 1180-1183

Sudhakar P, Vu Q, Lasaki OK, Palmer M. Upper Eyelid Ptosis Revisited. American Journal of Clinical Medicine 2009:66(3).pp.5-13

Biswas A. Classification of ptosis. In: Color Atlas of Oculoplastic and Orbital Disorders. New Delhi: Jaypee;2009.pp.192-217

Biswas A. Surgical Management of Ptosis. In: Color Atlas of Oculoplastic and Orbital Disorders. New Delhi: Jaypee;2009.pp.220-247

Wong VA et al. Management of Myogenic Ptosis. Ophthamlology 2012:109.pp.1023-1031

Rizvi SAR, Yousuf S, Gupta Y. Surgical Management of Congenital and Aponeurotic PtosisCosmetic Outcome. Austin J Clin Ophthalmol 2014:1(7).pp.1-3

Matayoshi S, Pereira IC, Rossato LA. Surgical Treatment of Congenital Blepharoptosis. Rev Bras Ophthalmol 2014: 73(4). Pp.202-209

Kim CY, Yoon JS, Bae JM, Lee SY. Prediction of Postoperative Eyelid Height After Frontalis Suspension Using Autogenous Fascia Lata for Pediatric Congenital Ptosis. Am J Ophthalmol 2012:153.pp.334-342

Colin JRO. Ptosis. In: A Manual Of Systematic Eyelid Surgery. London: Churchill Livingstone;1989.pp.41-72.

Lane CM, Collin JR. Treatment of Ptosis in Chronic Progressive External Ophthalmoplegia. Br J Ophthalmol 1987: 71.pp. 290-294

Skuta GL, Cantor BL, Weiss JS.Periocular Malpositions and Involutional Changes. In: Orbit,Eyelid and Lacrimal System. San Fransisco : American Academy of Ophthalmology Section 7; 2011-2012.pp. 201-213

Betharia SM, Dayal Y, Kalra BR. Surgical Management of Blepharophimosis Syndrome. Indian J Ophthalmol 1983: 31(4).pp. 339-341

Goldberg RA, Lew H. Cosmetic Outcome of Posterior Approach Ptosis Surgery (an American Ophthalmological Society Thesis). Trans Am Ophthalmol Soc 2011: 109.pp.157-167 